\title{
Growing Pomegranates in Florida: Establishment Costs and Production Practices ${ }^{1}$
}

\author{
Feng Wu, Zhengfei Guan, and Gary Vallad ${ }^{2}$
}

\section{Introduction}

Pomegranate, native to central Asia and mainly produced in India and Iran, is highly adaptive to a wide range of climates and soil conditions, and can grow in many geographical regions. In the United States, California is the major production area. Pomegranate has long been valued for its high nutritional value. Research shows that pomegranate has marked antioxidant, antibacterial, anti-inflammatory, antiviral, and anti-carcinogenic activities, and has efficacy against a series of human diseases (Viuda-Martos et al. 2010). With increasing awareness of its health benefits, consumers have shown growing interest in consuming pomegranate fruits and juices. In Florida, pomegranate is an emerging, alternative crop to major crops under tremendous competition pressure (e.g., tomato and strawberry) or threatened by serious diseases (e.g., citrus greening). This study provides a description of pomegranate production practices and preliminary cost estimates to inform investment and production decisions when growers look to diversify and grow pomegranate as a niche crop.

Currently, Florida pomegranate production is still in an early stage, with about 150 acres in production (Florida Pomegranate Association 2017). There is keen interest from growers about the cost of establishment and production. Pomegranate grove care practices include establishment, irrigation, pruning, fertilization, and pest management.

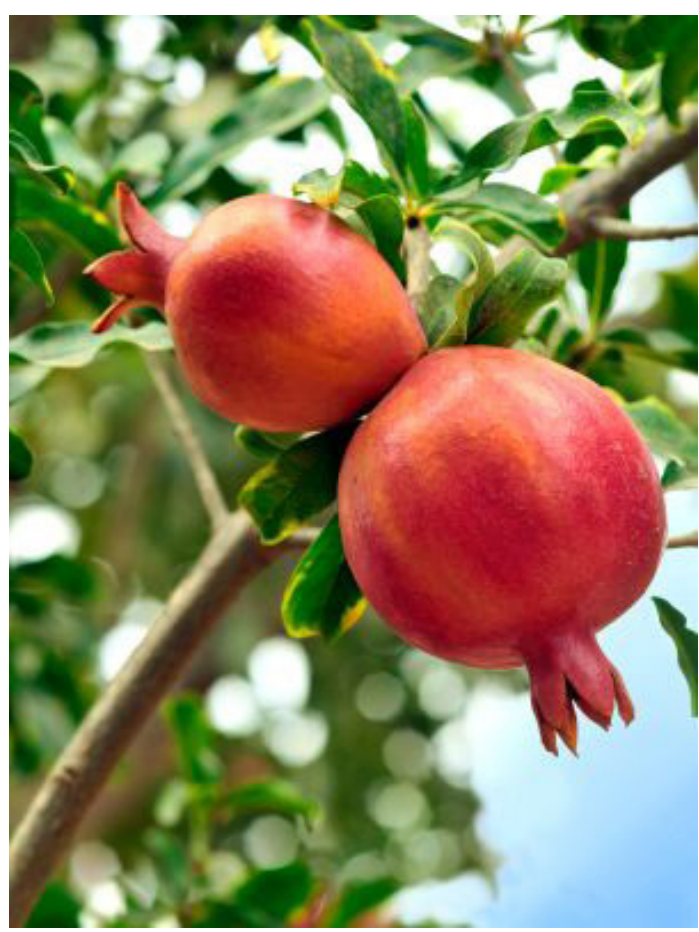

Credit: USDA

This article provides cost estimates on these practices for a mature grove ( $3+$ years old) (Tables 1 and 2). These costs reflect current establishment and cultural practices but do not cover harvest and post-harvest information. The cost data were collected through personal interviews with six pomegranate growers in fall 2014. The sample, which covers major promegranate operations in Florida, is relatively small because the industry is still emerging in

1. This is EDIS document FE1024, a publication of the Food and Resource Economics Department, UF/IFAS Extension. Published July 2017. Visit the EDIS website at http://edis.ifas.ufl.edu.

2. Feng Wu, research assistant scientist, Food and Resource Economics Department, UF/IFAS Gulf Coast Research and Education Center, Balm, FL; Zhengfei Guan, assistant professor, Food and Resource Economics Department, UF/IFAS Gulf Coast Research and Education Center, Balm, FL; and Gary Vallad, associate professor, Plant Pathology Department, UF/IFAS Gulf Coast Research and Education Center, Balm, FL.

The Institute of Food and Agricultural Sciences (IFAS) is an Equal Opportunity Institution authorized to provide research, educational information and other services

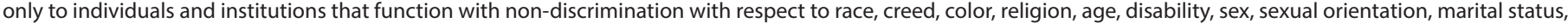

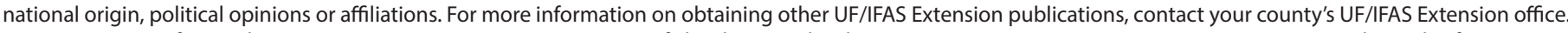
U.S. Department of Agriculture, UF/IFAS Extension Service, University of Florida, IFAS, Florida A \& M University Cooperative Extension Program, and Boards of County Commissioners Cooperating. Nick T. Place, dean for UF/IFAS Extension. 
the state. The interviewed growers plant pomegranate for commercial opportunities. Because Florida pomegranate production is still in its infancy and production practices vary significantly across growers, the costs described in this study are incomplete and provide only a reference for cost items discussed, which could be useful for those who are looking to invest in pomegranate production. The total establishment cost of a pomegranate orchard is approximately $\$ 4,000$ per acre (Table 1 ). The total cultural cost (includes fertilization, weed management, and pruning) of a pomegranate orchard is approximately $\$ 1,030$.

\section{Establishment}

Growers planted the container-grown transplants on a $12^{\prime} \times 18^{\prime}$ spacing, with 202 trees per acre. A wider spacing of $18^{\prime} \times 18^{\prime}$ is used in Georgia and California. Single-trunk trees require less space than bushes, which have broader canopies. Pomegranate cuttings are generally propagated in one-gallon or three-gallon pots in nurseries. One-gallon potted plants are less than one year old and cost $\$ 8$ to $\$ 12$ in 2014, while three-gallon potted plants are taller and older and cost $\$ 20$ to $\$ 25$, depending on the varieties. The planting labor cost is estimated at \$2 per tree. After the plants are set in the field, pine bark mulch is applied to aid in plant establishment (Figure 1). Mulch moderates soil temperature, aids in weed control, and adds organic matter to the soil. A pine bark strip about 4 feet wide extending down the row provides a good substrate for surface feeder roots (Williamson et al. 2012). The mulch cost is estimated at $\$ 2$ per tree.

A large number of cultivars grown in California, Georgia, and other countries are available for Florida growers, but selecting cultivars that perform well in Florida in terms of growth, flowering, and fruiting is still a challenge. The University of Florida is collaborating with Florida pomegranate growers in experimental trials to identify optimal cultivars suited for Florida. The preliminary results show there are some yield merits in the Girkanets, Kazake, Wonderful, Al-sirin-nar, and Medovyi Vahsha varieties (Castle and McTeer 2016).

\section{Irrigation}

Irrigation systems are installed during the first year of establishment, right before planting. The most common irrigation system used is drip emitters or microsprinklers (also known as "microjets"). Drip emitters discharge 0.5 to 2.0 gallons per hour, while microsprinklers commonly deliver 7 to 25 gallons per hour (Parsons and Morgan 2014). Drip emitters provide low volume irrigation and small coverage for root systems, so it is appropriate for

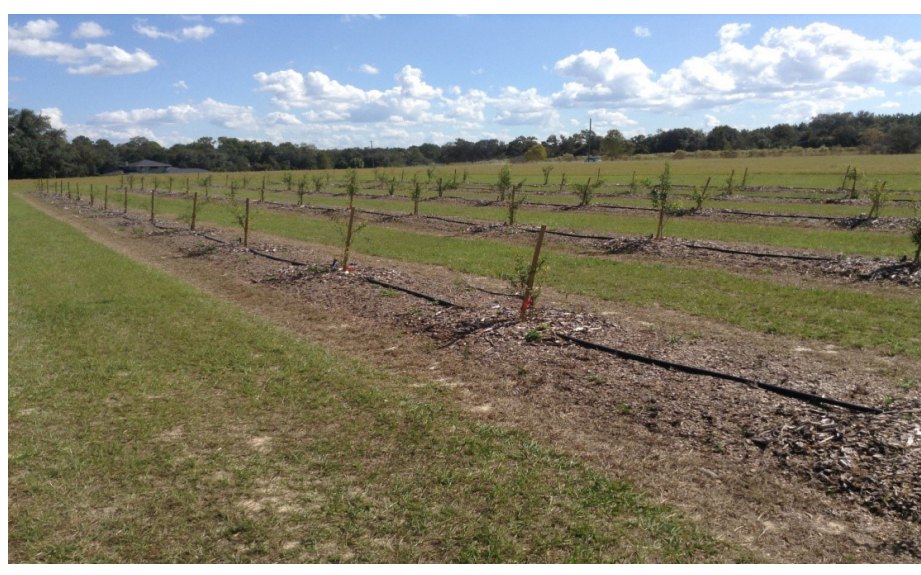

Figure 1. Mulch application in pomegranate groves.

Credits: GREC

groves with young trees. When roots of mature trees extend horizontally throughout much of the soil area, more surface coverage will be required because better surface area coverage can optimize yields in Florida's sandy soils (Parsons and Morgan 2014). Alternative methods to increase coverage are to add more drippers per tree or change drip emitters to microsprinklers (Figure 2).

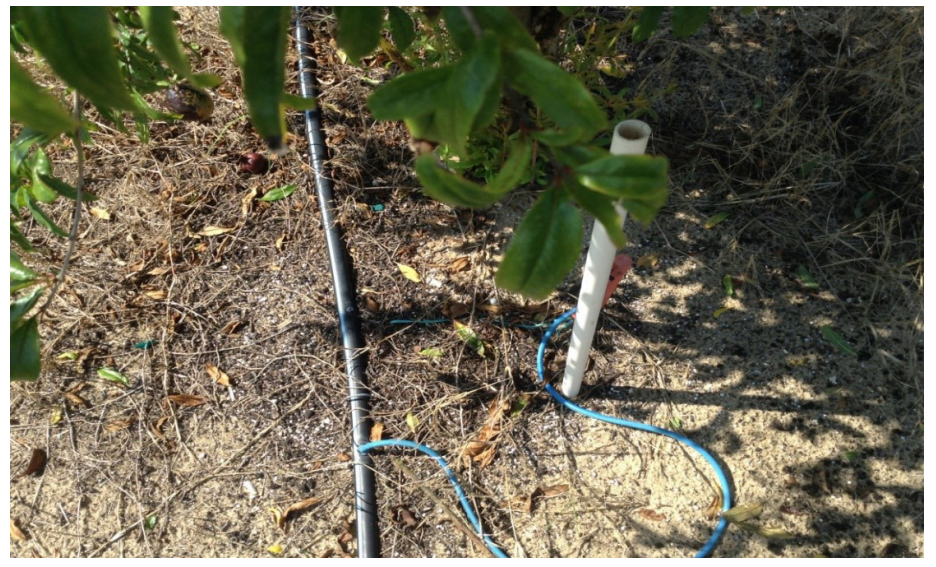

Figure 2. Microsprinkler irrigation Credits: GREC

Microsprinklers are installed at ground level or on short risers to irrigate an area measuring between 5 and 21 feet in diameter. In addition to larger volume irrigation, microsprinklers provide cold protection, which has also proved effective for citrus (Parsons and Boman 2013). The establishment cost of an irrigation system includes the materials cost ( $\$ 800$ per acre) for microsprinklers and installation labor cost ( $\$ 400$ per acre).

Water use directly affects pomegranate yield and fruit quality. The frequency of irrigation depends on several factors, such as temperature, rainfall, type of soil, and age of trees. During the dry season, for trees planted in central ridge sandy soil, growers irrigate only once per week for 15-20 minutes for trees less than one year old, and twice per week 
for about 60 minutes each time for trees more than 2 years old. In areas with clay soil, growers often do not need to irrigate their trees. Over-irrigation can cause fruit split. The optimal irrigation practices for pomegranate trees require further research.

\section{Pruning}

Pruning time varies across the types of training practiced, labor skill, and age of trees. Pomegranate trees do not require extensive pruning in the early years. In the first year, growers remove suckers originating from below ground. After the first year, single-trunk trees need more pruning than bushes. The growers interviewed suggest removing small tree branches if they are dead, damaged, or crisscrossed. Bushes have a broad, tight canopy, so pruning excessive branches creates more access to light, less damage to fruit from thorny branches, and easier harvesting. Mature trees and bushes are pruned on a regular basis, with heavier pruning in spring and winter than in summer. It is estimated that it takes 11 hours to prune one acre of trees/bushes in summer, compared to 32 hours in spring and 48 hours in winter. The total labor cost for pruning is estimated at $\$ 722$ (assuming the minimum wage was paid).

\section{Fertilization}

Fertilization is important for pomegranate trees. Young trees are fertilized every 1 to 2 months, and the amount of fertilizer applied increases each year. Trees more than 3 years old receive 3 to 4 nutritional sprays during the year. One practice adopted by a grower is to apply 82 pounds per acre nitrogen fertilizer, 224 pounds per acre 10-10-10 (nitrogen-phosphorous-potassium) fertilizer, and 300 pounds per acre 8-6-8 fertilizer. Besides fertilizers, foliar micronutrients are also applied each month as a supplement. The fertilization cost of this practice is estimated to be $\$ 162$ per acre.

\section{Weed Management}

Like blueberry growers, pomegranate growers use a system of weed-free strips under the trees. A weed-free zone under the trees can reduce the impact of weeds on tree growth (Dittmar and Williamson 2012). Generally, a strip of 4-5 feet wide is maintained weed free. Turfgrass is mowed or chemically controlled on a regular basis. The herbicides are applied with a broadcast sprayer connected behind a tractor. The weed-free zone is sprayed 2 to 3 times each year, which could occur in March, June, and October. To reduce the chance of herbicide resistance, herbicides should be rotated.

\section{Insects and Diseases}

Growers need to evaluate the economic risk from pest and disease infestation through scouting and to determine pest and disease control strategy. Dipel, sulfur, and other insecticides are applied to control insects. Aphids have been identified as one of the primary pests in pomegranate trees/ bushes. The application frequency depends on current and expected pest pressure and the life cycle of pests. Disease control is important in Florida due to its subtropical, warm, humid climate. Growers have to apply fungicides routinely, in contrast to the occasional application of insecticides. Some diseases found include but are not limited to Cercospora, Botryosphaeria, Anthracnose, and Alternaria leaf blight. Fungicide-resistant diseases are a growing concern for growers. Typically, a fungicide application plan is adopted prior to the season, in which fungicides that have different modes of action are alternated each month.

\section{Concluding Remarks}

The Florida pomegranate industry is still in its early stage. Most orchards are small in size, and large-scale commercial production has yet to be seen. Growers have shown a keen interest in the crop but have little economic information on pomegranate establishment, production, and marketing. The University of Florida has made some progress in plant breeding and best management practices, but more research needs to be done. The information from this study should be used with caution because of the relatively small sample size from a small population. To make more informed production decisions, growers can explore research from other states. California grows most of the nation's commercial pomegranates and has developed a mature cultivation and management system. Georgia has also made significant progress in pomegranate production and management in recent years. Their information could be a useful resource for Florida growers. Growers can consult the United States Department of Agriculture's specialty crops webpage (USDA 2017) to obtain price information.

\section{References}

Castle, B., and E. McTeer. 2016. "Pomegranates in Florida

- Really?" Citrus Industry, August, pp. 32-34.

Dittmar, P., and J. Williamson. 2012. Weed Management in Blueberry. HS90. Gainesville: University of Florida Institute of Food and Agricultural Sciences. http://edis.ifas.ufl.edu/ wg016

Florida Pomegranate Association (FPA). 2017. Director (Ms. Cindy Weinstein) Personal Communication with Zhengfei Guan, June 5, 2017. 
Parsons L. R., and B. J. Boman. 2013. Microsprinkler

Irrigation for Cold Protection of Florida Citrus. HS931.

Gainesville: University of Florida Institute of Food and

Agricultural Sciences. http://edis.ifas.ufl.edu/ch182

Parsons, L. R., and K. T. Morgan. 2014. Management of Mi-

crosprinkler Systems for Florida Citrus. HS958. Gainesville:

University of Florida Institute of Food and Agricultural

Sciences. http://edis.ifas.ufl.edu/hs204

United States Department of Agriculture (USDA). 2017.

Market News: Specialty Crops. Washington, DC: USDA.

https://www.marketnews.usda.gov/mnp/fv-home.

Viuda-Martos, M., J. Fernández-López, and J.A. Pérez-

Álvarez. 2010. "Pomegranate and Its Many Functional

Components as Related to Human Health: A Review."

Comprehensive Reviews in Food Science and Food Safety

9(6):635-654.

Williamson, J.G., P.M. Lyrene, and J.W. Olmstead. 2004.

Blueberry Gardener's Guide. CIR1192. Gainesville: Univer-

sity of Florida Institute of Food and Agricultural Sciences.

http://edis.ifas.ufl.edu/mg359 
Table 1. Establishment Costs of Pomegranate in Florida

\begin{tabular}{|l|c|}
\hline Items & Value (\$/acre) \\
\hline Trees & 2,020 \\
\hline Planting labor costs & 404 \\
\hline Mulch & 404 \\
\hline Irrigation system & 800 \\
\hline Installing Irrigation system & 400 \\
\hline Total establishment costs & 4,028 \\
\hline
\end{tabular}

Table 2. Cultural Costs of Pomegranate in Florida

\begin{tabular}{|l|c|}
\hline Items & Value (\$/acre) \\
\hline Fertilizer & 162 \\
\hline Herbicides & 146 \\
\hline Pruning & 722 \\
\hline Total cultural costs & 1,030 \\
\hline
\end{tabular}


